Section Editor

John J. Millichap, MD

Pearls \& Oy-sters:

\title{
An uncommon initial presentation of thyrotoxicosis
}

\section{PEARLS}

Parneet K. Grewal, MBBS

Mauricio F. Villamar, MD

Flavius D. Raslau, MD

Michael R. Dobbs, MD, MHCM

Correspondence to

Dr. Dobbs:

mrdobb0@uky.edu
- Venous thrombosis is common in patients with thyrotoxicosis, with the cerebral venous system being frequently involved.

- Full anticoagulation with unfractionated heparin or low molecular weight heparin is the treatment of choice for cerebral venous sinus thrombosis (CVST), even for patients with hemorrhagic complications.

- Evaluation of thyroid function tests should be considered as a part of the diagnostic workup for patients who are diagnosed with CVST when its underlying etiology remains elusive.

\section{OY-STERS}

- Development of headache or focal neurologic deficits in a patient with thyrotoxicosis should prompt clinicians to evaluate for CVST.

CASE REPORT A 22-year-old man was brought to the emergency department by his family after he had 2 witnessed spells of involuntary, rhythmic movements of the right lower extremity that then generalized to the whole body. There were associated rhythmic eyelid and jaw movements. He had been drowsy for a few days prior and had been complaining of a constant holocranial headache that worsened when leaning forward. Other symptoms included hyporexia, cold sweats, subjective fevers, and diarrhea.

The patient had been diagnosed with Graves disease 1 year prior and started on methimazole. However, he had not taken it for the last 3 months. There was no history of seizures, head trauma, or CNS infections. There was no family history of seizures, although there were relatives with hypothyroidism.

On arrival, the patient was tachycardic, hypertensive, and diaphoretic. He was somnolent but easily arousable. There was no obvious papilledema on direct nondilated ophthalmoscopy. Cranial nerves were normal, and there were no focal motor or sensory deficits.
Thyroid-stimulating hormone (TSH) was undetectable and free T4 was above the upper limit of detection. He was started on methimazole along with propranolol for thyrotoxicosis secondary to medication noncompliance. Given the recent events concerning for seizures, the patient was loaded with levetiracetam and placed on a maintenance dose.

CT of the head without contrast revealed a hyperdensity in the superior sagittal sinus (figure). MRI brain with and without gadolinium suggested a dural venous sinus thrombosis in the superior sagittal sinus and cortical swelling and vascular congestion in the left parietal region. The latter could be explained by impaired cortical venous drainage in this territory and would be consistent with the patient's seizure semiology involving the right lower extremity. Magnetic resonance venogram (MRV) with gadolinium confirmed extensive venous sinus thrombosis of the superior sagittal sinus (figure) as well as mild thrombosis of the right transverse and sigmoid sinuses. A routine 30-minute EEG performed interictally revealed diffusely slow background with no epileptiform discharges. Funduscopic examination performed at this time, 5 days after admission, showed interval development of bilateral grade 3 papilledema, likely secondary to increased intracranial pressure due to CVST.

A workup for hypercoagulability revealed elevated levels of factor VIII $(>300 \%$, with reference range $56 \%-91 \%)$. IV unfractionated heparin was started with aggressive hydration.

No further seizures were noted. Six days after admission, thyroid function tests were rechecked. TSH was still undetectable, but free T4 had decreased to $3.5 \mathrm{ng} / \mathrm{dL}$ (reference range $0.8-17.7 \mathrm{ng} / \mathrm{dL}$ ). The patient was discharged in stable condition on warfarin and was scheduled to follow-up in 3 months with a repeat MRV of the head. The importance of medication compliance was emphasized.

DISCUSSION CVST has an incidence of approximately 3-4 cases per million in adults and 7 cases per million in children. ${ }^{1}$ The pathogenesis of CVST involves thrombosis of either cerebral veins or major

From the Departments of Neurology (P.K.G., M.F.V., M.R.D.) and Radiology (F.D.R.), University of Kentucky, Lexington.

Go to Neurology.org for full disclosures. Funding information and disclosures deemed relevant by the authors, if any, are provided at the end of the article. 


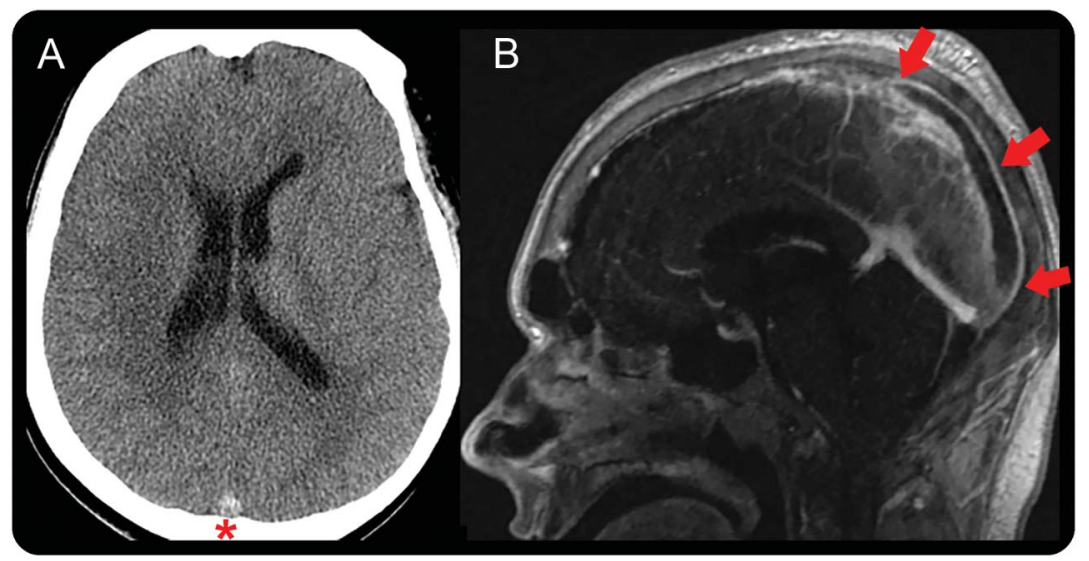

(A) Hyperdensity on axial noncontrast CT (asterisk) and (B) filling defect on sagittal contrast-enhanced magnetic resonance venogram (arrows) confirm thrombus.

sinuses, both of which can lead to intracranial hypertension. Venous thrombosis can be promoted by 3 factors, which are referred to as the Virchow triad: hypercoagulability, stasis of blood flow, and abnormalities of the blood vessel wall. Some common clinical conditions that can predispose to CVST include hereditary thrombophilia, pregnancy and puerperium, postoperative states, intracranial or local infections, and use of oral contraceptive pills or other hormonal supplements. Approximately $25 \%$ of cases of CVST are considered to be idiopathic. ${ }^{2}$

The association between thyrotoxicosis and thrombosis was first described by Kaliebe in $1913 .^{3}$ Since then, it has been noted that among patients with thyrotoxicosis and venous thrombosis, as many as $80 \%$ of thrombotic phenomena can occur in unusual locations, such as splanchnic veins and the cerebral venous system. ${ }^{4}$

The exact pathophysiologic mechanisms explaining the relation between thyrotoxicosis and thrombosis are not fully understood and there is insufficient evidence to demonstrate a strong causal relation between these 2 phenomena. ${ }^{4,5}$ However, it has been hypothesized that changes in the levels of thyroid hormones can lead to disequilibrium in the coagulation cascade. Hyperthyroidism can result in either increased synthesis or impaired clearance of multiple proteins that are mainly derived from the vascular endothelium, leading to elevated levels of molecules such as factor VIII, factor IX, von Willebrand factor, fibrinogen, fibronectin, and plasminogen activator inhibitor-1, therefore favoring a procoagulant state. ${ }^{4,6}$ Among these molecules, factor VIII has been more widely studied in thyrotoxicosis. Epinephrine infusions in healthy subjects are followed by increased factor VIII activity. Since hyperthyroid patients have increased sensitivity to the effects of catecholamines, it is possible that in these cases even physiologic concentrations of epinephrine can enhance factor VIII activity. Similarly, normalization of factor VIII levels after euthyroid state is reached has been reported. ${ }^{7}$ Recently, a locus on chromosome 18 was identified near D18S53. This gene is involved in the pleiotropic modulation of factor VIII activity and activated protein $\mathrm{C}$ resistance, suggesting a link between these 2 variables and susceptibility to thrombosis. ${ }^{8}$ Finally, another contributing mechanism to the development of CVST in these patients could be compression of the axillary and subclavian veins resulting in venous stasis, which can be purely due to mass effect from an enlarged thyroid gland. ${ }^{?}$

Common manifestations of CVST include headache, vision problems, and focal neurologic deficits such as paresis or seizures. Seizures, which could be focal or generalized, occur in about $40 \%$ of patients, which is much more common than in patients with arterial infarcts. The highly variable clinical presentation of CVST sometimes leads to delays in diagnosis and treatment. ${ }^{1}$

The most sensitive neuroimaging modality for CVST consists of MRI in combination with MRV.$^{10}$ Rarely, if diagnosis is still uncertain, cerebral angiography may be needed. Initial treatment for CVST consists of anticoagulation with unfractionated heparin infusion or with low molecular weight heparin to arrest thrombosis and to prevent further elevations in intracranial pressure. Anticoagulation has been shown to be safe even in patients with hemorrhagic transformation secondary to CVST (Class IIa; Level of evidence B). ${ }^{10}$ Oral acetazolamide can be considered for treatment of intracranial hypertension (Class IIa; Level of evidence C). ${ }^{10}$ Other possible therapeutic options include endovascular thrombolysis or thrombectomy (Class IIa; Level of evidence 
C). ${ }^{10} \mathrm{~A}$ case report of plasma exchange for the treatment of the CVST secondary to thyrotoxicosis has been published, but this treatment modality needs to be studied further. ${ }^{11}$

The development of headache or focal neurologic deficits in a patient with thyrotoxicosis should prompt clinicians to evaluate for CVST. Similarly, although thyroid function can be abnormal in the setting of acute illness, ${ }^{12}$ evaluation of thyroid function tests should be considered as a part of the diagnostic workup for patients who are diagnosed with CVST when its underlying etiology remains elusive.

\section{AUTHOR CONTRIBUTIONS}

Parneet K. Grewal: case concept and design, acquisition of data, interpretation of data, manuscript writing. Mauricio F. Villamar: case concept and design, acquisition of data, interpretation of data, manuscript writing. Flavius D. Raslau: neurodiagnostic evaluation, critical revision of manuscript for intellectual content. Michael R. Dobbs: case concept and design, interpretation of data, critical revision of manuscript for intellectual content.

\section{STUDY FUNDING}

No targeted funding reported.

\section{DISCLOSURE}

The authors report no disclosures relevant to the manuscript. Go to Neurology.org for full disclosures.

\section{REFERENCES}

1. Stam J. Thrombosis of the cerebral veins and sinuses. New Engl J Med 2005;352:1791-1798.

2. Bousser MG, Chiras J, Bories J, Castaigne P. Cerebral venous thrombosis: a review of 38 cases. Stroke 1985; 16:199-213.
3. Kaliebe H. Autochthone Sinusthrombose bei einem Falle von Morbus Basedow und Tabes. Med Klin 1913;9:1929-1932.

4. Franchini M, Lippi G, Targher G. Hyperthyroidism and venous thrombosis: a casual or causal association? A systematic literature review. Clin Appl Thromb Hemost 2011;17:387-392.

5. Lerstad G, Enga KF, Jorde R, et al. Thyroid function, as assessed by TSH, and future risk of venous thromboembolism: the Tromso study. Eur J Endocrinol 2015;173:83-90.

6. Debeij J, Cannegieter SC, Van Zaane B, et al. The effect of changes in thyroxine and thyroid-stimulating hormone levels on the coagulation system. J Thromb Haemost 2010;8:2823-2826.

7. Simone JV, Abildgaard CF, Schulman I. Blood coagulation in thyroid dysfunction. N Engl J Med 1965;273: 1057-1061.

8. Soria JM, Almasy L, Souto JC, et al. A new locus on chromosome 18 that influences normal variation in activated protein C resistance phenotype and factor VIII activity and its relation to thrombosis susceptibility. Blood 2003;101:163-167.

9. Klaasen-Udding LM, Van Lijf JH, Ten Napel CH. Substernal goitre, deep venous thrombosis of the arm, and Pemberton's sign. Neth J Med 1983;26:228-231.

10. Saposnik G, Barinagarrementeria F, Brown RD Jr, et al. Diagnosis and management of cerebral venous thrombosis: a statement for healthcare professionals from the American Heart Association/American Stroke Association. Stroke 2011;42:1158-1192.

11. Usami K, Kinoshita T, Tokumoto K, et al. Successful treatment of plasma exchange for severe cerebral venous thrombosis with thyrotoxicosis. J Stroke Cerebrovasc Dis 2009; 18:239-243.

12. Economidou F, Douka E, Tzanela M, Nanas S, Kotanidou A. Thyroid function during critical illness. Hormones 2011;10:117-124. 


\section{Neurology}

\section{Pearls \& Oy-sters: An uncommon initial presentation of thyrotoxicosis \\ Parneet K. Grewal, Mauricio F. Villamar, Flavius D. Raslau, et al. \\ Neurology 2017;89;e61-e63 \\ DOI 10.1212/WNL.0000000000004213}

This information is current as of August 7, 2017

\section{Updated Information \& Services}

References

Subspecialty Collections

Permissions \& Licensing

Reprints including high resolution figures, can be found at: http://n.neurology.org/content/89/6/e61.full

This article cites 12 articles, 4 of which you can access for free at: http://n.neurology.org/content/89/6/e61.full\#ref-list-1

This article, along with others on similar topics, appears in the following collection(s):

All Cerebrovascular disease/Stroke

http://n.neurology.org/cgi/collection/all_cerebrovascular_disease_strok

Cerebral venous thrombosis

http://n.neurology.org/cgi/collection/cerebral_venous_thrombosis

Endocrine

http://n.neurology.org/cgi/collection/endocrine

Stroke in young adults

http://n.neurology.org/cgi/collection/stroke_in_young_adults

Information about reproducing this article in parts (figures,tables) or in its entirety can be found online at:

http://www.neurology.org/about/about_the_journal\#permissions

Information about ordering reprints can be found online:

http://n.neurology.org/subscribers/advertise

Neurology ${ }^{\circledR}$ is the official journal of the American Academy of Neurology. Published continuously since 1951, it is now a weekly with 48 issues per year. Copyright (O 2017 American Academy of Neurology. All rights reserved. Print ISSN: 0028-3878. Online ISSN: 1526-632X.

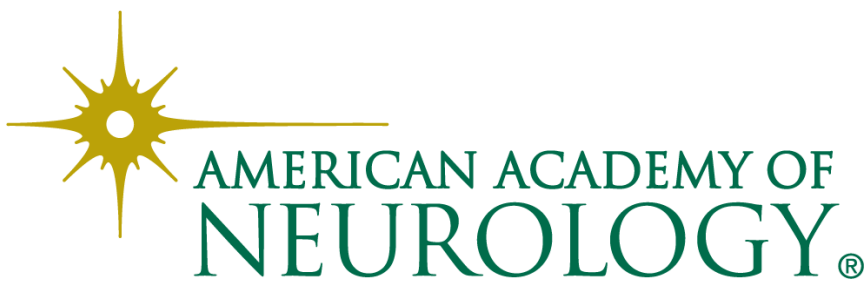

